\title{
Methodology for the study of the conceptual foundations of pension legislation in the United Kingdom, France, and Russia
}

\author{
Anna Viktorovna Aleksandrova ${ }^{11}$, Angelina Vyacheslavovna Lapaeva ${ }^{2}$, Anastasia Andreevna \\ Ryzhova $^{1}$, and Elena Alekseevna Serebryakova ${ }^{3}$ \\ ${ }^{1}$ Penza State University, Department of State and Legal Disciplines. Law Institute, Penza, Russia \\ ${ }^{2}$ Derzhavin Tambov State University, Department of Theory and History of State and Law, Tambov, \\ Russia \\ ${ }^{3}$ National Research University, Higher School of Economics, School of Theory of Law and \\ Cross-sectoral Legal Studies, Moscow, Russia
}

\begin{abstract}
The study's objective is to develop a methodology for studying the conceptual foundations of pension legislation in three countries: the United Kingdom, France, and Russia. The following methods were used to perform the tasks set out in the introduction: analysis and synthesis, induction and deduction, systematic, sociological, statistical, formal-legal, comparative-legal, historical, and legal methods. The result of this work was the author's methodology for studying the conceptual foundations of pension legislation. This methodology includes the following elements: definition and justification of the subject of research, establishing its spatial and temporal framework, development and justification of the author's periodization of the conceptual foundations of pension legislation. In addition, as part of this study, the need to apply the conceptual foundations of pension legislation such methods of knowledge as dialectical approach, general scientific methods (analysis, synthesis, systematic), private scientific methods (sociological, statistical, mathematical), and private legal methods (formal-legal, comparative-legal, historical and legal) is justified. The choice of three specific countries is since they represent different models of pension provision and different legal families. The study proves the special methodological significance of considering pension as a combination of two interrelated elements: pension insurance and budget support. The study's novelty is due to the problem statement (the conceptual foundations of the pension legislation of the United Kingdom, France, and Russia are the first to appear as the subject of the study), as well as the interdisciplinary nature of the proposed approaches. The developed methodology can be used to study pension and other social security legislation and be extended to other countries as objects of study.

Keywords: pension provision, legislation, concept, research method
\end{abstract}

\section{Introduction}

\footnotetext{
${ }^{1}$ Corresponding author: ann-alexandrova@mail.ru
} 
This article presents the author's approaches to developing a methodology for the study of the conceptual foundations of pension legislation. The main background of the study is the need to form new conceptual approaches to the development of pension legislation due to the crisis of pension provision systems observed in recent decades in our country and abroad. The causes of this crisis include economic [1,2], demographic [3], ideological and socio-psychological $[4,5]$.

In connection with this, it is important to study the concepts underlying the pension legislation originally and currently in use. Research methods are of particular importance for solving this problem, and therefore the first stage of the work should be the development of a methodology. It is necessary to solve the following tasks to achieve this goal:

1) selection and justification of research methods for the conceptual foundations of pension legislation:

- universal (dialectical or metaphysical);

- general scientific;

- private-scientific (used by individual, non-legal sciences);

- private-legal (special-legal);

2) development of the author's methodology for studying the conceptual foundations of the pension legislation of the United Kingdom (UK), France, and Russia, including justification of the subject, theoretical and empirical base of research, justification of the choice of three countries for the purposes of the study, development of the author's periodization of the development of the conceptual foundations of pension legislation.

\section{Methods}

The following methods were used to perform the tasks set out in the introduction: analysis and synthesis, induction and deduction, systematic, sociological, statistical, formal-legal, comparative-legal, historical, and legal methods.

\section{$3 \quad$ Results}

Table 1 shows the main results.

Table 1. Main results.

\begin{tabular}{|c|l|l|}
\hline $\begin{array}{c}\text { No } \\
1\end{array}$ & $\begin{array}{l}\text { The } \\
\text { dialectical } \begin{array}{c}\text { universal } \\
\text { research } \\
\text { method was chosen }\end{array}\end{array}$ & $\begin{array}{l}\text { It is supposed to identify the conceptual foundations of the } \\
\text { pension legislation of the UK, France and Russia, and study the } \\
\text { experience of their implementation in practice, considering } \\
\text { different concepts concerning the historical situation in which it } \\
\text { was formed. }\end{array}$ \\
\hline 2 & $\begin{array}{l}\text { General scientific } \\
\text { methods were chosen: }\end{array}$ & $\begin{array}{l}\text { Dividing the subject into parts: sequential identification and } \\
\text { study of the conceptual foundations of the pension legislation of } \\
\text { three countries, first the UK, then France and Russia at each of } \\
\text { the distinguished development stages; }\end{array}$ \\
\cline { 2 - 4 } & $\begin{array}{l}\text { - analysis } \\
\text { - synthesis }\end{array}$ & $\begin{array}{l}\text { Combining the studied elements, forming a common } \\
\text { legislation, identifying common trends in their development; }\end{array}$ \\
\hline
\end{tabular}




\begin{tabular}{|c|c|c|}
\hline & - system method & $\begin{array}{l}\text { The authors consider pension legislation as a system of } \\
\text { normative acts in providing the population with monetary } \\
\text { payments in cases established by law, such as old age, } \\
\text { disability, survivorship, etc.; at the same time, pension } \\
\text { legislation is part of the system of social legislation, which, in } \\
\text { turn, is part of the legislation system of a particular country. }\end{array}$ \\
\hline \multirow[t]{4}{*}{3} & $\begin{array}{lr}\text { Private } & \text { scientific } \\
\text { methods } & \text { were } \\
\text { selected: } & \end{array}$ & \\
\hline & - sociological & $\begin{array}{l}\text { The use of sociological techniques to determine the } \\
\text { effectiveness of the implementation of a particular pension } \\
\text { concept; }\end{array}$ \\
\hline & - statistical analysis & $\begin{array}{l}\text { The use of quantitative indicators to determine the conditions } \\
\text { for the implementation of a particular concept, as well as to } \\
\text { assess its effectiveness; }\end{array}$ \\
\hline & - mathematical. & $\begin{array}{l}\text { Using mathematical calculations to determine the percentage of } \\
\text { people covered by a pension in a particular country. }\end{array}$ \\
\hline \multirow[t]{4}{*}{4} & $\begin{array}{l}\text { Private law methods } \\
\text { were chosen: }\end{array}$ & \\
\hline & - formal-legal & $\begin{array}{l}\text { Analysis of acts of pension legislation from the point of view of } \\
\text { legal technique, formal logic, analysis of the conceptual } \\
\text { construct; }\end{array}$ \\
\hline & - comparative law & $\begin{array}{l}\text { Using both synchronous comparisons (comparing the concepts } \\
\text { and norms of pension legislation in Russia, France, and the UK } \\
\text { during the same period) and diachronous comparisons } \\
\text { (comparing norms of pension legislation of one country during } \\
\text { different eras); }\end{array}$ \\
\hline & - historical and legal & $\begin{array}{l}\text { The study of the peculiarities of the formation of the conceptual } \\
\text { foundations of a particular country's pension legislation takes } \\
\text { into account the characteristics of the period in which the } \\
\text { formation and development of specific institutions and political } \\
\text { teachings took place. }\end{array}$ \\
\hline \multirow[t]{2}{*}{5} & $\begin{array}{l}\text { The author's } \\
\text { methodology for } \\
\text { studying the } \\
\text { conceptual } \\
\text { foundations of pension } \\
\text { legislation in the UK, } \\
\text { France, and Russia is } \\
\text { developed: }\end{array}$ & \\
\hline & $\begin{array}{l}\text { - the main concepts } \\
\text { that characterize the } \\
\text { subject of the study } \\
\text { are defined }\end{array}$ & $\begin{array}{l}\text { The conceptual foundations of pension legislation - a system of } \\
\text { theories, ideas used in the development of regulatory acts in } \\
\text { pension provision. } \\
\text { Pension is considered in a broad sense as a system that } \\
\text { combines pension insurance and budget support. }\end{array}$ \\
\hline & $\begin{array}{l}\text { - the theoretical and } \\
\text { empirical basis of the } \\
\text { study is determined }\end{array}$ & $\begin{array}{l}\text { Theoretical basis: political-legal, economic, philosophical, and } \\
\text { sociological teachings underlying the pension legislation of the } \\
\text { UK, France, and Russia. } \\
\text { Empirical base: acts of the pension legislation of the three } \\
\text { countries, as well as materials of judicial practice, collective } \\
\text { agreements, programs of political parties, and statistical data. }\end{array}$ \\
\hline
\end{tabular}




\begin{tabular}{|c|c|}
\hline $\begin{array}{l}\text { - the choice of specific } \\
\text { three countries for the } \\
\text { purposes of the study } \\
\text { is justified, }\end{array}$ & $\begin{array}{l}\text { The Russian experience should be studied due to the particular } \\
\text { social significance of the pension reforms of recent years, as } \\
\text { well as the lack of research on the theoretical foundations of } \\
\text { pension provision in our country. The UK and France are } \\
\text { attractive since they represent different legal families } \\
\text { (Anglo-Saxon and continental), different models of social } \\
\text { security (the Beveridge and Bismarck models), and are also } \\
\text { countries with a high level of socio-economic development. }\end{array}$ \\
\hline $\begin{array}{l}\quad \text { the author's } \\
\text { periodization of the } \\
\text { development of the } \\
\text { conceptual } \\
\text { foundations of pension } \\
\text { legislation has been } \\
\text { developed. }\end{array}$ & $\begin{array}{l}\text { Four main stages: } \\
\text { 1. The initial formation of the conceptual foundations of } \\
\text { pension legislation: before } 1914 \text {. By the beginning of the First } \\
\text { World War in the states under consideration, the foundations of } \\
\text { this legislation had been completed. The pension systems for } \\
\text { officials and servicemen were formed; the first laws on social } \\
\text { insurance for employees were adopted. } \\
\text { 2. Development of mandatory insurance principles in pension } \\
\text { provision (1914-1945). In the UK, compulsory pension } \\
\text { insurance was introduced in the 1920s. In Russia, pension } \\
\text { provision for the elderly was established in the 1930s. In } \\
\text { France, in 1930, the pension Law of } 1910 \text { was substantially } \\
\text { reformed. } \\
\text { III. Introduction of the principle of universal pension provision } \\
\text { (1945-1980). In the first post-war years, democratic forces and } \\
\text { supporters of social reforms came to power: the Labor Party in } \\
\text { Britain, the Socialists in alliance with the Communists in } \\
\text { France. Attempts were made to introduce the universality of } \\
\text { social security (including pensions), inspired by the ideas of W. } \\
\text { Beveridge. In the USSR, in the } 1950 \text { s, the first law on state } \\
\text { pensions was adopted (before that, subordinate laws were in } \\
\text { force), and in the } 1960 \text { s - the law on pensions for collective } \\
\text { farmers; that is, steps are being taken to introduce universal } \\
\text { pension provision. } \\
4 \text {. Pension system crisis (1980-2021). Economic and } \\
\text { demographic changes have reduced the number of contribution } \\
\text { payers relative to pension recipients; financial problems require } \\
\text { structural changes in pension systems. The coronavirus } \\
\text { pandemic is creating new challenges related to restrictions on } \\
\text { economic activity and forced mass unemployment. }\end{array}$ \\
\hline
\end{tabular}

\section{Discussion}

The conceptual framework can be considered the ideological core of the provisions consolidated in the pension legislation. In this sense, they are close to the concept of "source of law" in the philosophical aspect $[6,7]$. The concept of "pension provision" in legal and economic science is interpreted ambiguously. Broadly understood, pension provision is an institution that combines pension insurance and budgetary pension provision $[8,9]$. These elements of pension provision differ from each other in several criteria - first of all, by the funding source. If pension insurance is based on contributions from social partners, then budget support is provided exclusively at the expense of the budget. The second approach involves a narrow interpretation of the term "pension provision": equating it with the form we have called budget security above. Based on this, pension provision is contrasted with pension insurance [10]. 
In our opinion, when studying the conceptual foundations of pension legislation, it is necessary to proceed from a broad approach to understanding pension provision. We find a similar interpretation in works devoted to historical types of pension provision $[11,12]$.

In order to substantiate the author's periodization presented in the Results section, it is necessary to rely on the ideas available in science about the main stages in the evolution of political and legal thought $[13,14]$. It is also important to consider studies that present a periodization of the development of social state theory and practice [15-19].

In addition, identifying the main periods of development of the conceptual foundations of pension legislation is impossible without considering the main stages of development of social insurance and social security [10, 20-23].

\section{Conclusion}

It is necessary to use a set of methods: dialectical approach, analysis methods, synthesis, systemic, statistical, sociological, mathematical, comparative-legal, historical and legal, formal-legal approaches to study the conceptual foundations of pension legislation. The choice of the UK, France, and Russia is because they represent different models of pension provision and different legal families. The study is comparative-legal and historical-legal since it involves studying the formation and development of the conceptual foundations of pension legislation within specific periods. Of particular methodological importance is the consideration of pension provision as a set of interrelated elements: pension insurance and budgetary provision. The specifics of the research subject determine its interdisciplinary nature; it is carried out at the junction of legal sciences (History of Legal Studies, History of State and Law, Social Security Law) and other humanities (history, philosophy, sociology, economics).

The reported study was funded by RFBR, project No. 20-011-00252.

\section{References}

1. J.R. Hernández Pulido, Revista Latinoamericana de Derecho Social, 22, 101-160 (2016). https://doi.org/10.1016/j.rlds.2015.03.001

2. M.A. Morales Ramírez, Revista Latinoamericana de Derecho Social, 27, 131-157 (2018). https://doi.org/10.22201/iij.24487899e.2018.27.12532

3. Yu.V. Vasilyeva, S.V. Shuraleva, Bul. Perm Univ. Legal Sci. 41, 469 (2018)

4. A.M. Bonet de Viola, Revista Latinoamericana de Derecho Social, 26, 3-27 (2018). https://doi.org/10.22201/iij.24487899e.2018.26.11858

5. S. Baute, B. Meuleman, K. Abts, J. Soc. Pol. 48, 127-145, (2019). https://doi.org/10.1017/S0047279418000314

6. A.V. Malko, V.V. Nyrkov, Crim. J. Baikal State Univ. of Econ. and Law 6(3), 447-459 (2015)

7. Yu.A. Tikhomirov, Iss.State and Munic. Admin. 1, 136-159 (2019)

8. Yu.V. Vasilyeva, General issues of correlation between international and Russian Social Security Law, in E.G. Tuchkova, Yu.V. Vasilyeva (eds.), International and Russian social security norms: a comparative analysis (Prospekt, Moscow, 2013)

9. V.D. Roik, J. New Econ. Assoc. 3(27), 184-185 (2015)

10. S.A. Khmelevskaya, Pension insurance: philosophy, history, theory, and practice (Publishing and trading corporation "Dashkov and Co.", Moscow, 2018) 
11. D.B. Gusakov, Genezis gosudarstvennogo pensionnogo obespecheniya i sotsialnogo strakhovaniya v Rossiiskoi imperii: istoriko-pravovoi aspekt [Genesis of state pension and social insurance in the Russian Empire: historical and legal aspect]. Abstract of a $\mathrm{PhD}$ thesis in Legal Science (RANEPA, Saint Petersburg, 2015)

12. E.V.Sapilov, ECO J. 10, 181-190 (2004)

13. V.G. Grafsky, Istoriya politicheskikh i pravovykh uchenii: uchebnik [History of political and legal doctrines: textbook] (Legal Norm, SIC INFRA-M, Moscow, 2019)

14. M.N. Marchenko, Istoriya politicheskikh i pravovykh uchenii: uchebnik [History of political and legal doctrines: textbook] (Norma: INFRA-M, Moscow, 2019)

15. S.G. Kashchenko, M.A. Markova, O.V. Rodionova, Rus. Hist. J. 43(1), 169-178 (2017)

16. A.L. Fernandez-Alvarez, J. Instit. Stud. 4, 884-901 (2018). https://doi.org/10.21783/rei.v4i2.315

17. S. Koffas, Mediter. J. Soc. Sci. 10(1), 9-17 (2019). https://doi.org/10.2478/mjss-2019-0001

18. N.I. Lapin, Sociol. Stud. 8(412), 3-11 (2018). https://doi.org/10.31857/S013216250000758-6

19. Yu.D. Granin, Quest. Philos. 10, 11-16 (2019). https://doi.org/10.31857/S004287440007154-4

20. J. Bichot, Les politiques socialesen France au xx-e siècle (Armand Colin, Paris, 1997)

21. R.I. Ivanova, Sotsialnoe obespechenie v gosudarstvenno organizovannom obshchestve: genezis, razvitie i funktsionirovanie (pravovye aspekty) [Social security in a state-organized society: genesis, development, and functioning (legal aspects)]. Doctoral Thesis in Legal Science (Lomonosov Moscow State University, Moscow, 1987)

22. V.D. Roik, J. New Econ. Assoc. 3(27), 184-185 (2015)

23. Yu.V. Vasilyeva, Exjure, 4, 105 (2019) 